\title{
PERBEDAAN HASIL BELAJAR PESERTA DIDIK YANG MENDAPATKAN MODEL KOOPERATIF TIPE TEAMS-GAMES-TOURNAMENT DAN TIPE CONCEPT MAPPING PADA MATA PELAJARAN EKONOMI DI MAN BANJAR
}

\author{
Oleh: \\ Rita Patonah \\ Dosen Program Studi Pendidikan Akuntansi FKIP Universitas Galuh Ciamis \\ Jl. R. E. Martadinata No. 150 Ciamis, 46274 Jawa Barat \\ Email: ritapatonah@yahoo.com
}

\begin{abstract}
ABSTRAK
Hasil belajar yang rendah dari peserta didik adalah masalah yang dialami oleh sekolah, hal tersebut dapat tercermin dari nilai hasil belajar beberapa peserta didik belum memenuhi Kelima Kriteria Kelengkapan. Periset tertarik untuk melakukan eksperimen karena hasil belajar yang rendah dari peserta didik, untuk menciptakan suasana belajar yang lebih kreatif dan aktif demi terciptanya generasi penerus kualitas dan mampu bersaing di dunia global, sehingga peningkatan hasil belajar harus dilakukan secara optimal untuk mencapai tujuannya. Tujuan dari penelitian ini adalah: 1) Mengetahui peningkatan hasil belajar peserta didik yang mendapatkan model pembelajaran kooperatif tipe Team-Game-Tournament pada pretest dan posttest measurement; 2) Mengetahui peningkatan hasil belajar peserta didik yang mendapatkan model pembelajaran kooperatif tipe Concept Mapping pada pengukuran awal (Pretest) dan pengukuran akhir (Posttest); 3) Untuk mengetahui perbedaan dalam peningkatan hasil belajar antara peserta didik yang mendapatkan model pembelajaran kooperatif tipe Team-Game-Tournament dibandingkan dengan peserta didik yang mendapatkan model pembelajaran kooperatif tipe Concept Mapping pada pengukuran akhir (Posttest). Metode penelitian yang digunakan adalah metode eksperimen karena penelitian ini dilakukan untuk mengetahui fakta adanya gejala yang ada dan untuk mengetahui informasi secara faktual, terutama tentang data hasil belajar siswa. Jenis metode eksperimen yang digunakan dalam penelitian ini adalah Quasi Experimental Design Desain ini memiliki kelompok kontrol, namun tidak dapat berfungsi sepenuhnya untuk mengendalikan variabel luar yang mempengaruhi pelaksanaan percobaan. Berdasarkan hasil penelitian yang telah dilakukan menunjukkan bahwa terdapat peningkatan hasil belajar peserta didik yang mendapatkan model pembelajaran kooperatif tipe Team-Game-Tournament pada pretest dan posttest. Ada peningkatan hasil belajar peserta didik yang mendapatkan model pembelajaran kooperatif tipe Concept Mapping pada pretest dan posttest. Ada perbedaan yang signifikan dalam peningkatan hasil belajar peserta didik yang mendapatkan model pembelajaran kooperatif tipe Team-Games-Tournament dibandingkan dengan pembelajaran peserta didik yang mendapatkan model pembelajaran kooperatif tipe Concept Mapping pada pengukuran akhir (posttest).
\end{abstract}

Kata Kunci: Team-Game-Tournament, Concept Mapping, Learning Outcome

\section{PENDAHULUAN}

Belajar pada dasarnya ialah suatu perubahan pada peserta didik baik itu perubahan dalam aspek pengetahuan, sikap, maupun psikomotor. Salah satu tujuan dari pembelajaran yaitu tercapainya hasil belajar yang optimal. Hal ini sejalan dengan pendapat Suprijono (2013:7) "hasil belajar adalah perubahan perilaku secara keseluruhan bukan hanya satu aspek potensi kemanusiaan saja". Hasil belajar peserta didik ditentukan oleh faktor internal dan ekternal. faktor internal berasal dari dalam peserta didik itu sendiri sedangkan faktor eksternal berasal dari luar diri peserta didik yang salah satunya yaitu guru yang memberikan pengajaran
Proses penilaian terhadap hasil belajar dapat memberikan informasi kepada guru tentang kemajuan peserta didik. Berdasarkan pengamatan, hasil belajar yang diraih siswa belum optimal. Hal tersebut diantaranya dikarenakan kurangnya pemahaman peserta didik terhadap materi yang disampaikan. Hal ini dipengaruhi oleh pembelajaran yang berlangsung selama ini yang masih berpusat pada guru (teacher center) dan kurangnya variasi dalam pembelajaran, sehingga menjadikan peserta didik bosan dan pasif dalam berinteraksi untuk mendapatkan pengetahuannya. 
Berdasarkan observasi hasil belajar siswa Nilai Ulangan Tengah Semester dan wawancara kepada guru ekonomi di MAN Banjar, timbul masalah dalam kegiatan belajar mengajar di kelas. Hal tersebut dapat diketahui berdasarkan hasil belajar Ulangan Tengah Semester mata pelajaran Ekonomi. Untuk lebih jelasnya mengenai nilai peserta didik dapat dilihat pada tabel 1.1 yang merupakan nilai Ulangan Tengah Semester.

Tabel 1.1

Nilai Ulangan Tengah Semester Kelas XI.IIS MAN Banjar Tahun Ajaran 2017-2018

\begin{tabular}{|c|c|c|c|c|c|c|c|}
\hline \multirow{2}{*}{ Kelas } & \multirow{2}{*}{$\begin{array}{c}\text { Jumlah } \\
\text { Peserta } \\
\text { didik }\end{array}$} & \multirow{2}{*}{ KKM } & \multicolumn{5}{|c|}{ Nilai } \\
\cline { 4 - 8 } & $\begin{array}{c}\text { Nilai } \\
\text { Tertingi }\end{array}$ & $\begin{array}{c}\text { Nilai } \\
\text { terendah }\end{array}$ & $\begin{array}{c}\text { Dibawah } \\
\text { KKM }\end{array}$ & $\begin{array}{c}\text { Diatas } \\
\text { KKM }\end{array}$ & $\begin{array}{c}\text { Nilai } \\
\text { rata-rata }\end{array}$ \\
\hline XI.IIS 1 & 22 & 75 & 86 & 60 & 12 Orang & 10 Orang & 65 \\
\hline XI.IIS 2 & 26 & 75 & 92 & 61 & 12 Orang & 14 Orang & 71,5 \\
\hline
\end{tabular}

Sumber : MAN Banjar

Berdasarkan data di atas yaitu dalam tabel 1.1 dapat dilihat bahwa nilai ulangan tengah semester masih ada beberapa peserta didik yang belum memenuhi Kriteria Ketuntasan Minimal (KKM), yaitu 75,00. Peserta didik kelas XI.IIS MAN Banjar lebih banyak yang nilai UTS nya dibawah KKM. Berdasarkan hasil yang dilakukan dengan guru mata pelajaran, salah satu faktor yang menyebabakan rendahnya nilai peserta didik karena model pembelajaran yang kurang tepat serta guru kurang memberikan kesempatan kepada peserta didik untuk mengembangkan pengetahuannya melalui pembelajaran yang lebih aktif.

Berkenaan dengan permasalahan yang telah diuraikan maka diperlukan solusi atau pemecahan masalah dalam mengoptimalkan proses pembelajaran guru memilih model yang tepat dengan materi pembelajaran, tujuan pembelajaran, kemampuan dasar peserta didik supaya memberikan pemahaman materi kepada peserta didik. Guru harus mampu menyiasati tipe-tipe atau model-model apa saja yang cocok digunakan oleh seorang guru pada saat proses pembelajaran. Ada beberapa model yang bisa diterapkan oleh seorang guru dalam pembelajaran, salah satunya menggunakan model pembelajaran kooperatif (cooperative learning). penulis bermaksud menggunakan model pembelajaran kooperatif tipe TeamsGames-Tournament (TGT) dan tipe Concept Mapping. Miftahul Huda (2016:116-117) menyatakan bahwa:

Teams-Games-Tournament dikembangkan oleh slavin dan rekan-rekannya, penerapan TGT mirip dengan STAD dalam hal komposisi kelompok, format instruksional, dan lembar kerjanya." Bedanya, STAD fokus pada komposisi kelompok berdasarkan kemampuan, ras, etnik, dan gender, maka TGT umumnya fokus hanya pada level kemampuan saja. Selain itu, jika dalam STAD, yang digunakan adalah kuis, maka dalam TGT istilah tersebut biasanya berganti menjadi game akademik., peserta didik dibagi menjadi beberapa kelompok sehingga anak dapat lebih berperan aktif dalam proses belajar mengajar.

Dalam pembelajaran Ekonomi, kenyataan dilapangan masih menggunakan tipe yang statis. Sehingga peserta didik mengalami kejenuhan dalam proses pembelajaran. Belajar ekonomi memerlukan variasi dan langsung dihubungkan dengan kenyataan dilapangan sehingga peserta didik dapat lebih memahami pelajaran yang disampaikan. Peserta didik harus lebih aktif daripada pendidik, ruh yang diciptakan oleh pendidik mempunyai peranan yang sangat penting dalam kegiatan belajar.

Hal ini mempunyai korelasi dengan kurikulum 2013 yang diterapkan di Indonesia. Kurikulum 2013 menekankan pada dimensi pedagogik modern dalam pembelajaran, yaitu menggunakan pendekatan ilmiah. Pendekatan ilmiah (scientific approach) dalam pembelajaran sebagaimana dimaksud meliputi mengamati, menanya, mencoba, mengolah, menyajikan, menyimpulkan, dan mencipta untuk semua mata pelajaran khususnya pelajaran Ekonomi.

Tipe pembelajaran Concept Mapping $(C M)$ adalah tipe pembelajaran yang merupakan 
strategi dalam pembelajaran yang baik sekali sebab memaksa peserta didik untuk aktif memikirkan hubungan-hubungan di antara konsep-konsep atau faktor-faktor sains (ilmu pengetahuan), dengan kata lain bahwa sebagai strategi untuk mengakses pengetahuan struktur pengetahuan peserta didik. Peta konsep adalah gabungan beberapa konsep yang menghubungkan pengetahuan individu dengan topik pembelajaran. Peta konsep dihasilkan dengan mengidentifikasi konsep-konsep yang relevan. Menurut Martin (1994) dalam Trianto (2014: $185)$ "Peta konsep adalah ilustrasi grafis konkret yang mengindikasikan bagaimana sebuah konsep tunggal dihubungkan ke konsep-konsep lain pada kategori yang sama".

Untuk mengetahui perbandingan hasil belajar peserta didik antara metode yang satu dengan metode yang lainnya maka peneliti tertarik untuk membandingkan metode pembelajaran Teams-Games-Tournament yaitu strategi belajar peserta didik menggunakan kartu akademik dan permainan, dan metode pembelajaran Concept Mapping yaitu strategi dalam pembelajaran dengan peserta didik mencari pasangan sambil belajar mengenai suatu konsep atau topik, dalam suasana yang menyenangkan. sehingga berdampak pada hasil belajar peserta didik menjadi lebih baik.

\section{METODE PENELITIAN}

Metode yang digunakan dalam penelitian ini adalah tipe penelitian eksperimen. Bentuk desain eksperimen yang digunakan dalam penelitian ini adalah Quasi Experimental, yang dilakukan dengan memberikan perlakuan kepada subjek penelitian kemudian memberikan tes pada subyek penelitian.

Untuk mengetahui hasil penelitian, kedua kelompok eksperimen diberikan pretest dan posttest. Adapaun desain penelitian tersebut adalah sebagai berikut:

Tabel 3.1

Desain Eksperimen

\begin{tabular}{|c|c|c|c|}
\hline $\begin{array}{c}\text { Kelompok/ } \\
\text { kelas }\end{array}$ & Pretest & Treatment & $\begin{array}{c}\text { Tes } \\
\text { akhir }\end{array}$ \\
\hline XI. 1 & $\mathrm{O}_{1}$ & $\mathrm{X}_{1}$ & $\mathrm{O}_{3}$ \\
\hline XI. 2 & $\mathrm{O}_{2}$ & $\mathrm{X}_{2}$ & $\mathrm{O}_{4}$ \\
\hline \multicolumn{2}{|c}{ (Sugiyono, (2016: 79) }
\end{tabular}

Keterangan :

$\mathrm{O}_{1}$ : Tes awal (pretest) sebelum perlakuan diberikan kepada kelas eksperimen ${ }_{1}$.
$\mathrm{O}_{3}$ : Tes awal (pretest) sebelum perlakuan diberikan kepada kelas eksperimen ${ }_{2}$.

$\mathrm{O}_{2}$ : Tes akhir (posttest) setelah perlakuan diberikan kepada kelas eksperimen ${ }_{1}$.

$\mathrm{O}_{4}$ : Test akhir (posttest) setelah perlakuan diberikan kepada kelas eksperimen ${ }_{2}$.

$\mathrm{X}_{1}$ : Perlakuan (treatment) tipe Teams-GamesTournament (latihan) pada kelas eksperimen ${ }_{1}$.

$\mathrm{X}_{2}$ : Perlakuan (treatment) tipe Concept Mapping pada kelas eksperimen .

\section{HASIL PENELITIAN DAN \\ PEMBAHASAN}

Peningkatan Hasil Belajar Peserta Didik yang Mendapatkan Model Pembelajaran Kooperatif Tipe Teams-Games-Tournament Pada Pengukuran Awal (Pretest) dan Pengukuran Akhir (Posttest)

Berdasarkan nilai $N$-Gain, peningkatan hasil belajar peserta didik yang mendapatkan Model Pembelajaran Kooperatif tipe TeamsGames- setelah melaksanakan pretest dan posttest bernilai 0,57 , termasuk dalam kategori sedang atau berada pada interval $(0,30<\mathrm{g} \leq 0,70)$. Peningkatan hasil belajar peserta didik kelas XI.IIS 1 terjadi karena dalam kegiatan pembelajaran yang menggunakan tipe TeamsGames-Tournament peserta didik terlibat secara langsung dalam kegiatan belajar dan berperan aktif didalam kelas. Hal tersebut sesuai dengan pendapat Hamdani (2011: 92) "Pembelajaran kooperatif model TGT adalah salah satu tipe atau model pembelajaran kooperatif yang mudah diterapkan, melibatkan aktifitas seluruh siswa tanpa adanya perbedaan status, melibatkan peran siswa sebagai tutor sebaya, dan mengandung unsur permainan dan reinforcement."

Melalui penerapan model pembelajaran cooperative tipe Teams-Games-Tournament peserta didik dapat lebih kritis dan aktif memahami materi yang disampaikan. Dalam pembagian kelompok juga dibagi rata sesuai dengan tingkat kemampuan tanpa membedakan ras, suku, budaya dan jenis kelamin. Pengelompokkan tersebut berarti akan mengurangi kesenjangan diantara peserta didik, dan lebih mengedepankan sikap toleransi, sehingga peserta didik mempunyai nilai yang seimbang antara pengetahuan (kognitif), sikap (afektif) dan psikomotorik. Seperti halnya yang dikemukakan oleh Rusman (2016: 224) "TGT adalah salah satu tipe pembelajaran kooperatif yang menempatkan siswa dalam kelompokkelompok belajar yang beranggotakan 5 sampai 
6 orang siswa yang memiliki kemampuan, jenis kelamin dan suku kata atau ras yang berbeda." Selain itu model pembelajaran kooperatif tipe Teams-Games-Tournament dapat meningkatkan motivasi dan antusiasme peserta didik dalam belajar, karena diakhir pembelajaran guru memberikan reward kepada kelompok yang mendapatkan skor tertinggi dalam permainan. Hal tersebut pada akhirnya berdampak pada terjadinya peningkatan hasil belajar siswa.

Peningkatan Hasil Belajar Peserta Didik yang Mendapatkan Model Pembelajaran Kooperatif tipe Concept Mapping Pada Pengukuran Awal (Pretest) dan Pengukuran Akhir (Posttest)

Berdasarkan nilai $N$-Gain, peningkatan hasil belajar peserta didik yang mendapatkan model pembelajaran kooperatif tipe Concept Mapping pada peserta didik kelas XI.IIS 2 $\left(\right.$ Eksperimen $\left._{2}\right)$ setelah melaksanakan pretest dan posttest bernilai 0,41 termasuk kedalam kategori sedang atau berada pada interval $(0,30<\mathrm{g} \leq$ 0,70). Model pembelajaran kooperatif tipe Concept Mapping merupakan suatu cara mengajar yang melibatkan peserta didik dalam proses kegiatan untuk dapat mengilustrasikan sebuah konsep yang dihubungkan dengan konsep-konsep yang lain pada kategori yang sama. Sebagaimana menurut Martin dalam Trianto (2014:185) "Peta konsep adalah ilustrasi grafis konkret yang mengindikasikan bagaimana sebuah konsep tunggal dihubungkan ke konsepkonsep lain pada kategori yang sama."

Guru dapat melihat keaktifan peserta didik dalam bekerjasama membuat peta konsep yang baik dan mudah dipahami ketika dipresentasikan didepan kelas. Hal tersebut dapat merangsang kemampuan peserta didik untuk lebih kreatif dan aktif dalam pembelajaran. Dengan menerapkan metode pembelajaran Concept Mapping peserta didik mengingat materi pembelajaran dengan peta konsep. Materi yang disampaikan lalu didiskusikan dalam kelompok dibuat kedalam diagram yang memuat simbol, kode, gambar dan warna yang saling berhubungan. Hal tersebut membuat peserta didik lebih mudah mengingat materi pembelajaran

\section{Perbedaan Peningkatan Hasil Belajar Peserta Didik yang Mendapatkan Model Pembelajaran Kooperatif Tipe Teams- Games-Tournament Dibandingkan dengan Hasil Belajar Peserta Didik yang Mendapatkan Model Pembelajaran Kooperatif Tipe Concept Mapping pada Pengukuran Akhir (Posttest)}

Hasil penelitian menunjukkan terdapat perbedaan yang signifikan hasil belajar peserta didik yang mendapatkan model Pembelajaran Kooperatif tipe Teams-Games-Tournament dengan hasil belajar peserta didik yang mendapatkan model Pembelajaran Kooperatif tipe Concept Mapping.

Melalui penggunaan model pembelajaran kooperatif tipe Teams-Games-Tournament dapat meningkatkan kemampuan peserta didik dalam bekerja sama. Selain itu kemampuan komunikasi peserta didik juga lebih meningkat. Peserta didik belajar menghargai pendapat orang lain. Selain itu, model pembelajaran kooperatif tipe TeamsGames-Tournament juga dapat meningkatkan partisipasi dalam permainan yang mencerdaskan. Oleh karena itu, peserta didik akan lebih mudah dalam memahami materi pelajaran, karena materi diujikan melalui turnamen. Apabila peserta didik yang lain kurang memahami maka peserta didik yang paham dapat menjelaskan materi.

Melalui penerapan model pembelajaran kooperatif tipe Teams-Games-Tournament peserta didik lebih dapat menerima perbedaan individu dalam kelas. Peserta didik lebih menguasai materi secara mendalam dengan waktu yang singkat. Model pembelajaran kooperatif tipe Teams-Games-Tournamen melatih peserta didik untuk lebih aktif bersosialisasi dengan peserta didik yang lain dan meningkatkan kebaikan budi, kepekaan dan toleransi. Hal tersebut sejalan dengan pendapat ahli, menurut Taniredja (2015:72) adalah sebagai berikut:

Kelebihan pembelajaran kooperatif tipe Teams Games Tournaments (TGT) adalah:

a) Dalam kelas kooperatif mahasiswa memiliki kebebasan untuk berinteraksi dan menggunakan pendapatnya.

b) Rasa percaya diri mahasiswa menjadi lebih tinggi.

c) Perilaku mengganggu terhadap mahasiswa lain menjadi lebih kecil.

d) Motivasi belajar bertambah. 
e) Pemahaman yang lebih mendalam terhadap pokok bahasan pembelaan negara.

f) Meningkatkan kebaikan budi, kepekaan, toleransi, antara mahasiswa dengan guru.

g) Peserta didik dapat menelaah pokok bahasan bebas mengaktualisasikan diri dengan seluruh potensi yang ada dalam mahasiswa tersebut dapat keluar, selain itu kerjasama antar mahasiswa dan juga guru akan membuat interaksi belajar dalam kelas menjadi hidup dan tak membosankan.

Penerapan model pembelajaran kooperatif tipe Teams-Games-Tournament berbeda dengan tipe Concept Mapping. Didalam model pembelajaran kooperatif tipe Concept Mapping dibutuhkan waktu yang lama untuk menyusun peta konsep. Sedangkan waktu yang tersedia di kelas terbatas. Peserta didik sulit menentukan konsep-konsep yang terdapat pada materi yang dipelajari serta sulit mencari kata penghubung yang sesuai untuk menghubungkan satu konsep dengan konsep yang lain. Hal tersebut sesuai dengan pendapat Yusfi (2013: 45) yang menyatakan kekurangan dari tipe pembelajaran Concept Mapping antara lain :

1) Perlunya waktu yang cukup lama dalam menyusun peta konsep, sedangkan waktu yang tersedia di kelas sangat terbatas

2) Sulit menentukan untuk menghubungkan konsep yang satu dengan konsep yang lain.

3) Sebagian siswa merasa bahwa kegiatan belajar tidak menyenangkan karena kesulitan yang mereka hadapi.

Model pembelajaran kooperatif tipe Teams-Games-Tournament dan tipe Concept Mapping memiliki peran positif dalam meningkatkan hasil belajar peserta didik. Hal tersebut dibuktikan dengan terjadinya peningkatan hasil belajar peserta didik yang mendapatkan model pembelajaran kooperatif tipe Teams-Games-Tournament maupun tipe Concept Mapping. Namun demikian, peningkatan hasil belajar yang mendapatkan model pembelajaran kooperatif tipe TeamsGames-Tournament lebih tinggi dibandingkan dengan peserta didik yang mendapatkan model pembelajaran kooperatif tipe Concept Mapping. Hal tersebut membuktikan bahwa terdapat perbedaan hasil belajar peserta didik yang mendapatkan model pembelajaran kooperatif tipe Teams-Games-Tournament dengan model pembelajaran kooperatif tipe Concept Mapping

\section{PENUTUP}

Berdasarkan hasil penelitian dan pembahasan yang penulis sajikan, maka dapat disimpulkan bahwa:

1) Terdapat peningkatan hasil belajar peserta didik yang mendapatkan model Pembelajaran Kooperatif tipe Teams-Games-Tournament pada pengukuran awal (pretes) dan pengkuran akhir (posttest).

2) Terdapat peningkatan hasil belajar peserta didik yang mendapatkan model Pembelajaran Kooperatif tipe Concept Mapping pada pengkuran awal (pretes) dan pengukuran akhir (posttest).

3) Terdapat perbedaan yang signifikan antara hasil belajar peserta didik yang mendapatkan model Pembelajaran Kooperatif tipe TeamsGames-Tournament dengan hasil belajar peserta didik yang mendapatkan model Pembelajaran Kooperatif tipe Concept Mapping pada pengukuran akhir (posttes

\section{DAFTAR PUSTAKA}

Hamdani. 2011. Strategi Belajar Mengajar. Bandung: CV Pustaka Setia.

Huda, Miftahul. 2014. Model-Model Pengajaran dan Pembelajaran. Yogyakarta: Pustaka Pelajar.

Rusman. 2016. Model-model Pembelajaran. Jakarta. PT. Raja Grafindo Persada.

Slavin, Robert E. 2011. Psikologi Pendidikan. Jakarta Barat: PT. Indeks.

Sugiyono. 2011. Tipe Penelitian Kuantitatif Kualitatif dan $R \& D$. Bandung: Alfabeta.

-------. 2013. Tipe Penelitian Pendidikan (Pendekatan Kuantitatif, Kualitatif, dan $R \& D)$. Bandung: Alfabeta.

Suprijono, Agus. 2013. Cooperative Learning Teori dan Aplikasi PAIKEM. Yogyakarta: Pustaka Pelajar.

Taniredja et al. 2015. Model-Model Pembelajaran Inovatif dan Efektif. Bandung: Alfabeta.

Trianto. 2014. Mendesain Model Pembelajaran Inovatif, Progresif dan Kontekstual. Jakarta: Kencana. 
